Thrust Programs for Power Limited Propulsion Systems, Astron. Acta, Vol. 8 (1962), pp. 205-
227.

\title{
最近の航空機の新技術（その 1$)^{*}$
}

\section{1. 緒言}

最近米国においては，航空機の開発にあたりコスト 設計 (Design-to-Cost) が強調され，またコストを論ず るにもライフ・サイクル・コストと称して，購入時の コストだけでなく，購入後使用者の負担となる維持コ スト (Cost-to-Ownership) を含めて評価が行なわれる など，第 1 図に示すごとく努力の重点が大きく変わり つつあることは事実である.

そこで性能向上や重量軽減の努力が軽視され，新技 術開発は今後重要度が低下するといった判断が出ては 重大な誤りであることを，強く警告したい，性能向上 以外の努力目標む，スローガンだけ揭げておれば達成 されるすのではなくて，効果的な成果を上げるには新 技術の開発がぜひとも必要である，新技術の成果を適 用する方向が変わってきただけであることを強く指摘 したい.

第 2 困は最近のコスト設計の概念を導入した場合の 開発目標設定の原則を示すすのである，横軸の技術水 準 100\%は，現時点における最高水準であって，過去 の飛行機設計にさいしては，米国であ日本でむてれを ねらって全努力を傾注したものである，しかし最近で は，図に示すでとくコストや複雑さが横軸の $100 \%$ に 近つくにつれて急激に増大することを考慮して，A点 を設計の目標值に巽ふ上う，使用者之契約者が十分劦 議することが正当な方法となりつつある.

新技術の開発㹸よって。技術水準が仮に $20 \%$ 向上 すると，右側の曲楾上の B 点すなわち以前における 100\% 目標が，コストを考慮した性能の目標值として 選定できるようになる。

新技術開発の成果をコスト低減の目的に応用した具 体例というととができよう。

コスト設計の具体例として後述する米国ボーイング 社の YC-14 の場合においてむ，Supercritical 翼断

* 昭和 52 年 11 月 11 日, 飛行機シンポジゥムの特別請演之 して発表. 昭和 53 年 3 月 10 日原稿受理 Introducing Advanced Technologies in Recent Aircraft Designing and Manufacture (Part 1)

** 日本航空宇宙工業会 Shoichi TAKAYAMA
高 山 捷 一**

面と USB (Upper Surface Blowing) と称する推力利 用の高揚力装置の開発注っって，量産時のコスト見皘 りを目標値にまで引き下げることに成功している.

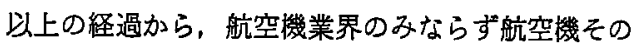
あのの進歩発展のためにも, 新技術の研究開発の重要 性はいぜんとして簃存するとの認識のむとに，最近 の航空機の新技術と新概念の一部を紹介するとととし た. なんらかの参考としてお役に立てば筆者望外の喜 びである.

\section{2. 亜音速機の新技術}

\subsection{Supercritical 翼断面}

2.1.1 従来の翼断面の問題点 従来の翼断面を使 用したジェット機は，0.8M（マッ八，高度 $10,668 \mathrm{~m}$ で $460 \mathrm{kt}$ ) 以下では経済的な巡航が可能であるが, $0.8 \mathrm{M}$ を超えると翼上面の空気の流㣗は部分的に超音 速となり，さらに速度が増大すると，翼上面の超音速 流は急激化加速して強い衙揧波が発生し，抵抗が急增 して空力的巡航効率は急激偟下し，さらに機体のバ フェッティングを生起するに至る（第 3 困，第 4 図参 照).

1960 年代後半まで飛行機設計者は，主翼の後退角・ 㨭り下げ・薄翼の採用などの方法で， $M_{\mathrm{cr}}$ (限界マッ 八数，Critical Mach Number）を大きくする努力を 行なってきた.

2.1.2 Supercritical 翼断面の開発 そのころ NASA (National Aeronautics and Space Administration）の Dr. R. T. WhiтcomB はこの問題に対し基本 的な接近を試み第 5 困に示すごとき新しい翼断面を開 発し, Supercritical Wing と命名した.

第 5 図には，従来の翼断面と此較して形状および上 下面の速度分布が示されているが，新断面の特色をひ とくちでいえば，抵抗增加の原因となる衝撃波の強さ を減少するための努力の具現というととができる，そ のために，大きな前縁の $\mathrm{R}$ と曲率の小さい平らな上面 を与えている，翼の強度および然料のための容積確保 のために必要な翼厚を保持するために，下面前部のふ くらみを大きくしている，そのため前部で減少した揚 力を補うために，下面後部のキャンバーを增すと同時 


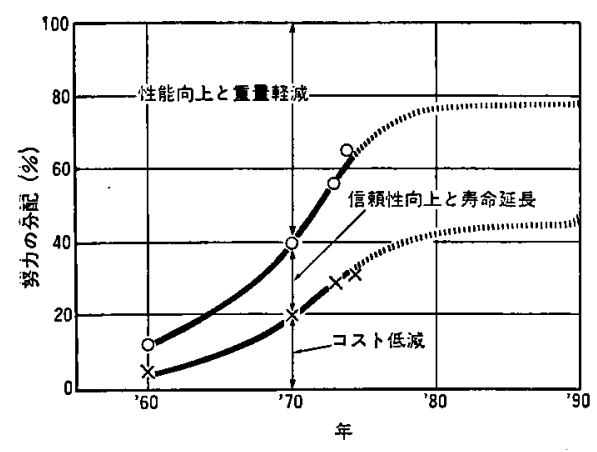

第 1 図 努力指向の变倦

口70 年江性能 - 重量飞 $60 \%$ ，信頼性 - 寿命に $20 \%$, 二 ストに $20 \%$ の努力配分がなされれたが，'80 年には信頼性 とコストに $80 \%$ 近い妰力が指向される傾向が見られる

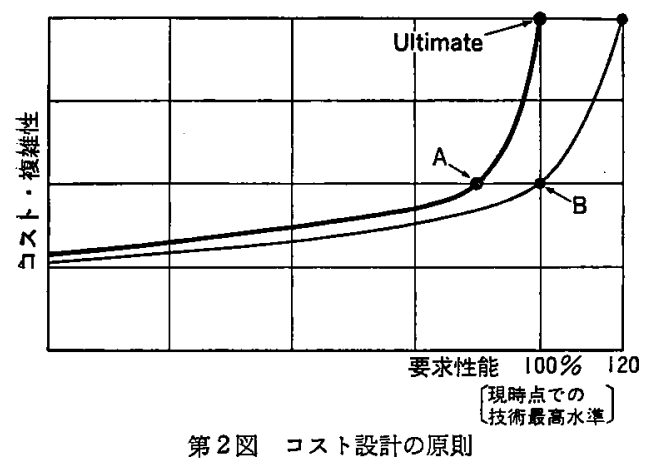

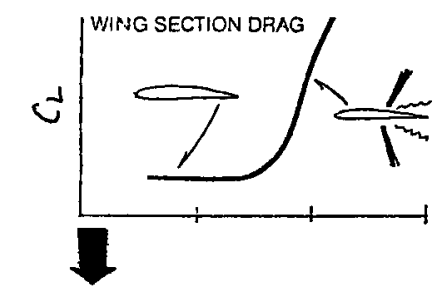
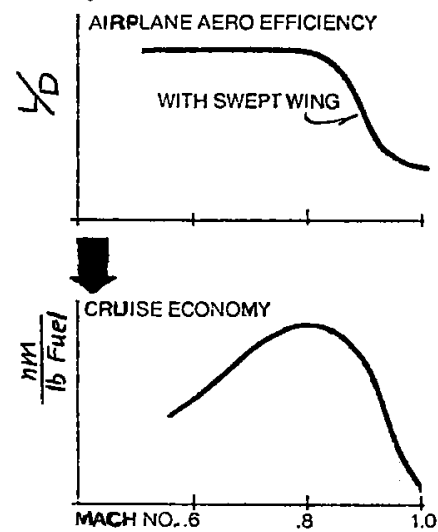

第 3 図 翼断面抵抗增加の汎航性能への影響
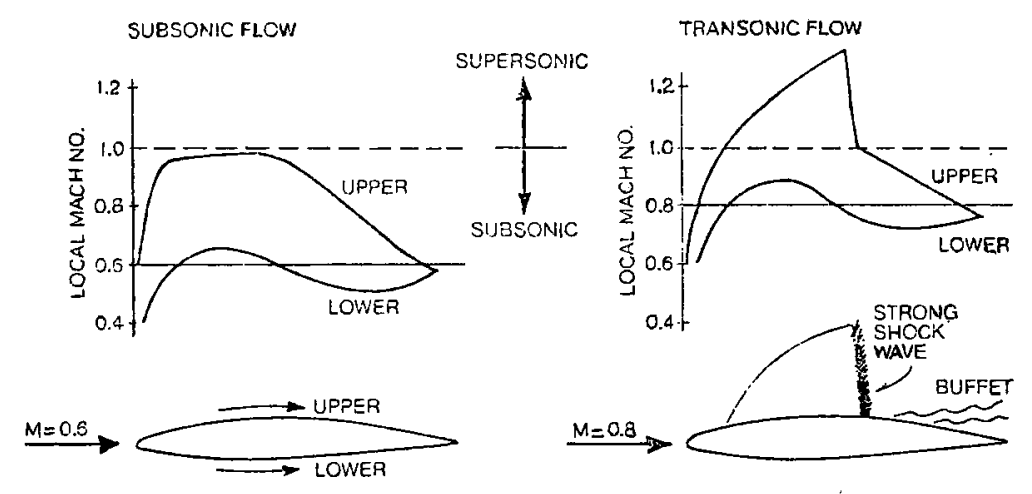

第 4 图 従来翼断面の特性

R，後縁に厚みを与えている。

成果としては，同じ厚さの断面で， $M_{\mathrm{cr}}$ は 12〜14 \% 増加している.

第 6 図は，Supercritical 翼断面の進歩の状況をボ ーイング社の歴代の代表的旅客機について比較したも のである. 横軸には後退角, 緃軸に翼厚(\%)をとり， 与えられだンジン推力で，所要の巡航速度を満たす ための条件を示したすのである，同じ後退角であれ 牥新しい翼ほど厚翼の使用が可能となり, 同じ翼厚 なら小さい後退角で斉むととがわかる. 今年の後半に
は開発仪着手するといわれる $7 \mathrm{X} 7(\mathrm{XY})$ は，最新の Supercritical 翼断面の採用により，747 より後退角を $8^{\circ}$ 減らすととが可能といわれている.

\subsection{Winglet (翼端小翼)}

2.2.1 定義 Winglet は飛行機の性能および運航 経凧性を改善するための新技術の一つで，翼端にとり 付けられた垂直に近い縦ひれである.

2.2 .2 過去の研究の歴史と反省 むともと大型輸 送機の翼端渦を減少する手段として試験されたもので あるが，最近の NASA における Winglet の開発は最 


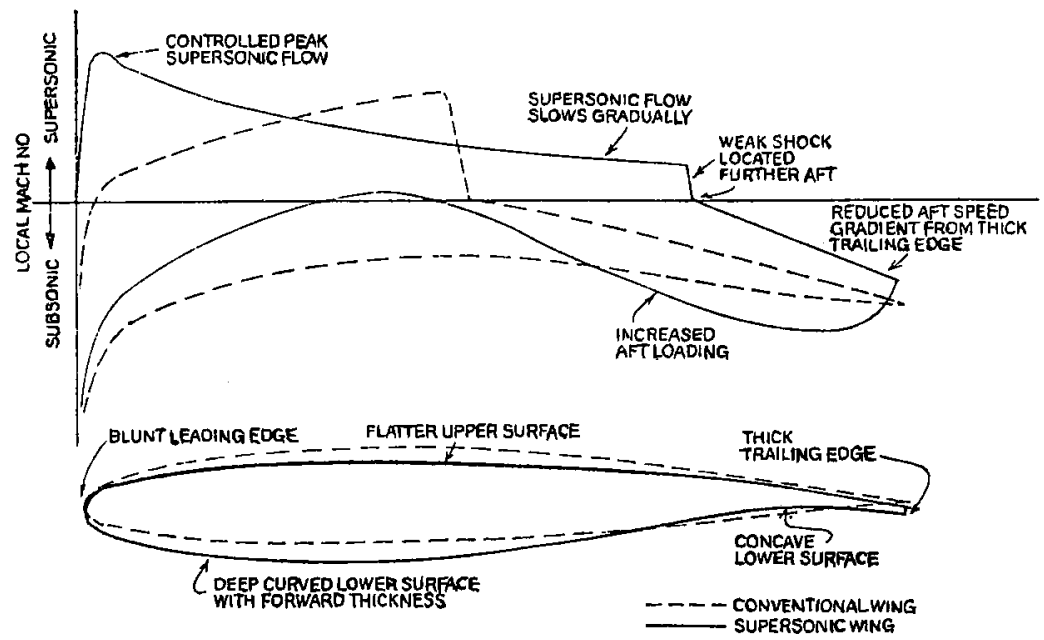

第 5 园 Supercritical 翼断面之従来翼の比較

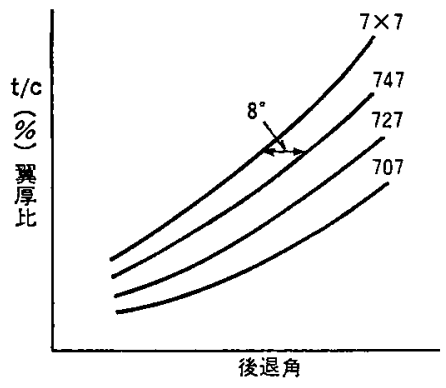

第6図 Supercritical 翼の効果

小の構造重量の增加で巡航効率を高めるための $L / D$ （揚抗比）の改良に重点がおかれている，

古くから翼端板を誘導抵抗の減少手段に利用できる ことは知られていたが，概して揚力の大きい条件下で しか有効でなかった，また曲げモーメントの増大によ る重量增加るばかにならず，むしろ翼端板だり翼端を 延長するほうが抵抗減少に㹥有効という結果が出てい た.

過去の研究で無視されていた点は，垂直面は効率よ く横力を発生しなければならぬという点であった。 こ の横力は翼端まわりの揚力による渦流を減少するのに 必要である．従来の翼端板はアスペクト比が概して小 さかったととも，揚力面として効果的でなかった一因 と考えられる.

2.2.3 新しい Winglet の開発 前記過去の翼端 板とは対照的に, Winglet はアスペクト比の大きい揚 力面である．翼端の渦流をつかまえて揚力を発生し， あわせて渦を拡散する働きをする（第 7 図参照），第 8 図に示すごとく翼端珮流固有の流れ角の関係で, Winglet の揚力は側方と同時に，前方の分力をむ発生 し，てれが抗力を減少する推力となる，むちろん細部
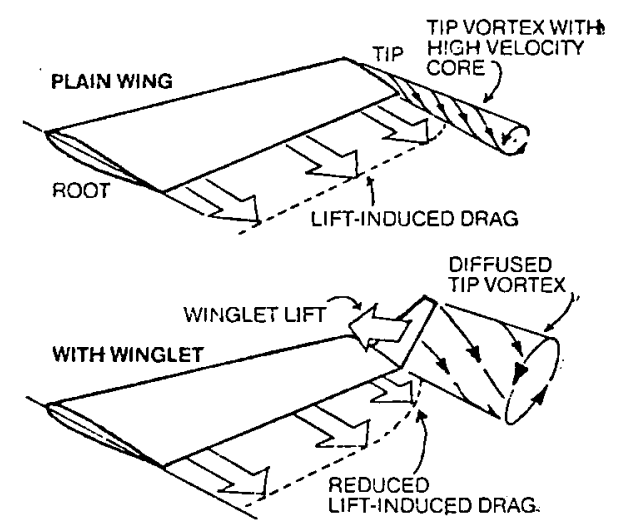

第 7 図 Winglets の翼端渦への影響

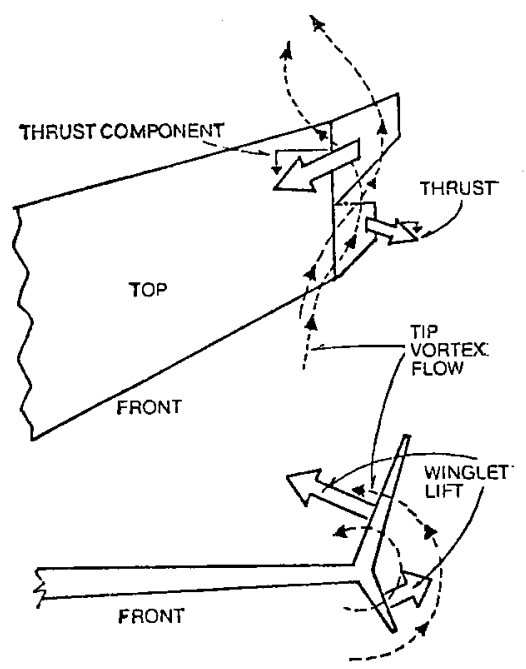

第 8 図Winglets の推力・揚力発生機構

は風胴試験によって最良の形状を求めなりればならな いが，NASA の成果によると全航空機の巡航効率の 


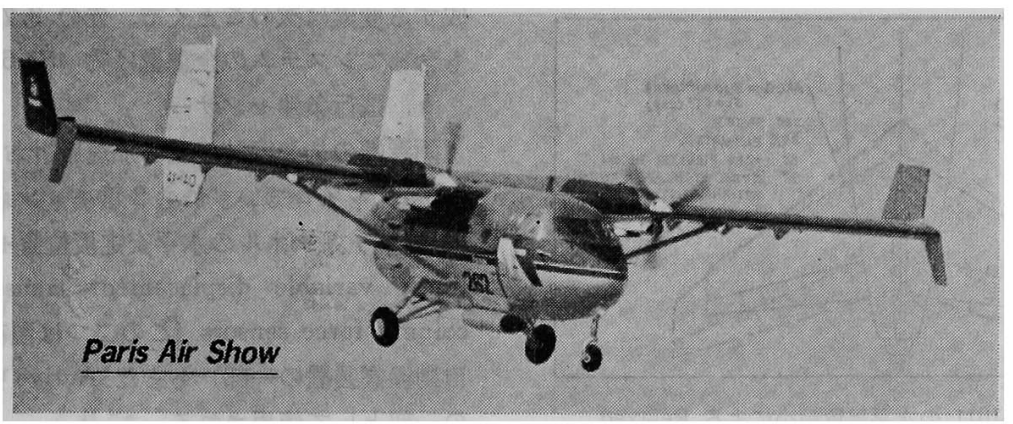

第 9 図 Araba 顽用䡕送機の Winglets (Israel A/C Ind.Itd.)

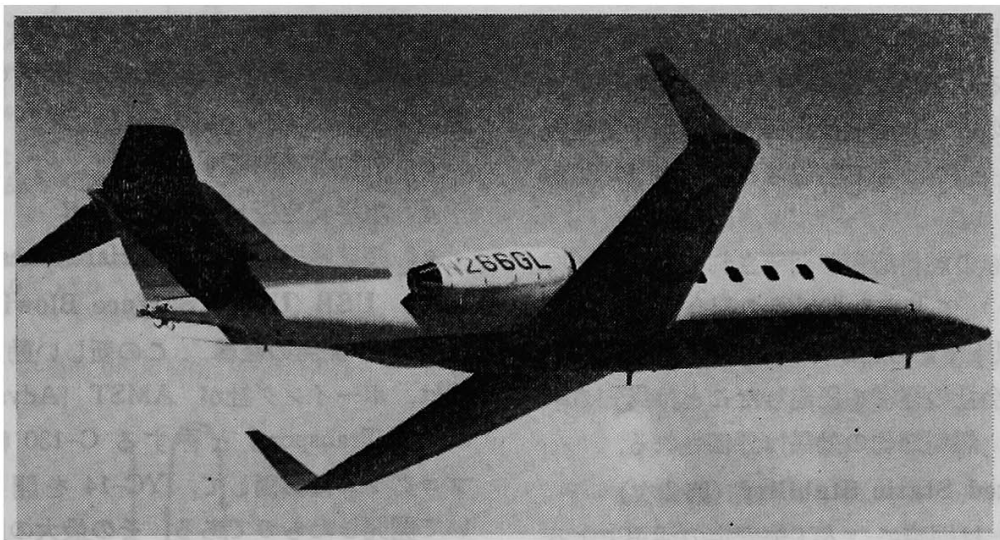

第 10 図 Gates Learjet 28/29 型の Winglets (Gates Learjet Corp.)
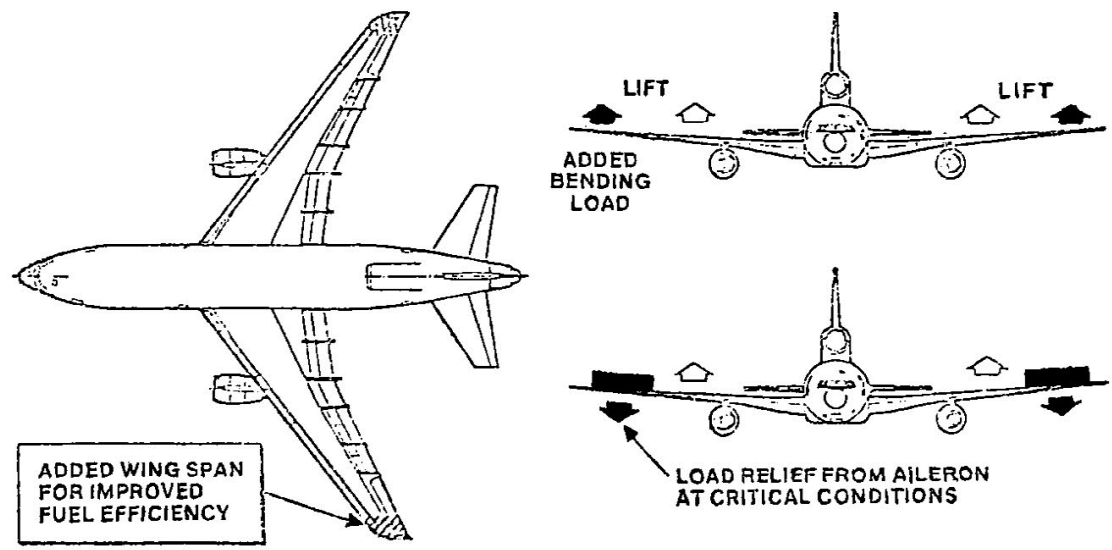

第 11 図 L-1011 の翼端延長と Active Control System

改善は 7\%を超えるといわれる.

またグラマン社では，一時 Gulfstream III と称す る新しい計画をむっていたが，その計画書によると， Winglet の採用によって, 翼面積を $8 \%$, 翼幅を 1.8 $\mathrm{m}$ 以上小さくすることが可能となり, その結果小型軽 量で経済的な輸送機が得られるとの結論が出されてい 万.

第 9 四および第 10 図はWinglet の実用例である.

\subsection{Active Control System ${ }^{1)}$}

2.3.1 L-1011 の改造計画（第 1 次） ロッキード 社が 1980 年以降出荷の旅客輸送機 L-1011 に適用を 予定し現在プロトタイプを改造して飛行試験中の新技 術である（昭和 52 年 9 月時点 60 回飛行).

改造された active 補助翼を左右同時に上方または 下方に作動して，翼端部に加る空気荷重を煘少し内 側に荷重を移動させる. かくして構造上の大きな再設 計を行なうととなく，翼幅を $2.74 \mathrm{~m}$ 延長し，アスペ 


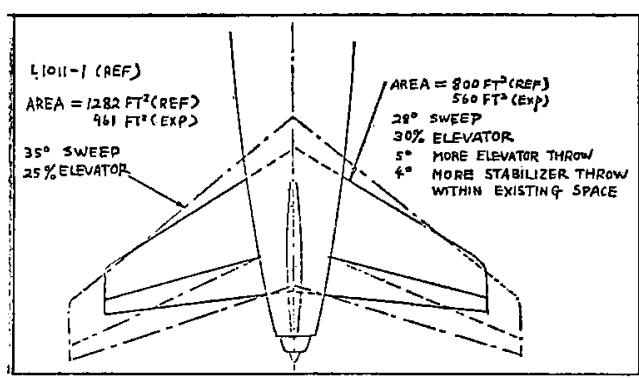

第 12 図 L-1011 の水平尾翠縮小による Relaxed Static Stability

クト比增大により L-1011 の巡航経済性を改善しよう とするすのである，とうぜん active 補助翼の作動保 よって生ずる縦のトリム変化は全面可動の水平安定板 を連動させるととによって処理される（第 11 因参 照).

その効果は $3 \%$ の燃料節約が期待されている. DOC （直接運航コスト）に占める燃料費の割合は，石油危 機以前は $20 \%$ 以下であったが，今日では $35 \sim 40 \%$ に あなって, 航空会社の経営を正迫したととは周知の事 実であるだけに，然料節約の効果は評価される.

\subsubsection{Relaxed Static Stability（第2次）}

Active Control は同時に，人工䋛安定の活用による いわゆる Relaxed Static Stability の採用を可能婂す る. 後述のでとくF-16 のでとき超音速援では，超音 速们打ける強すぎる縦安定（大きすぎる Static Margin）を解決するため，意識的に全機の重心を後退さ せ，亜音速域では Static Margin を負にして，Active Control によって静安定を維持しなからら，操維性の改 善や，航続性能の向上をはかっている，本機の場合に は，水平安定板の面皘を $119.2 \mathrm{~m}^{2}$ から $74.4 \mathrm{~m}^{2}$ に 減少し，抵抗の減少とあわせて $771 \mathrm{~kg}$ の重量軽減を はかっている(第 12 図参照).

乙の水平安定板の小型化は，L-1011 の燃費をさら 飞 $3.5 \%$ 減少し，第 1 次改修に上る効果之合わせると $6.5 \%$ の節約となる．乙の小型水平安定板への改造は 1983 年ない儿 1984 年以降の生産機に適用される計画 である.

2.3.3 付随的効用 Active Control は L-1011 の巡航経済性を改善するにとどまらず，操緥荷重制御 ・単性エードの挪圧および突風䌅和などによって飛行 性能の改善にも貢献する，操样荷重制御は两外側補助 翼の同時対称操作によって翼の空気荷重を再配分する ことによって実施される. また対称補助翼操舵は, 最 初の翼弾性曲げレスポンスを減衰させ, 翼の突風荷重 を減少する(「4. 戦闘機の CCV」の項参照).

2.3.4 追加搭載品 Active Control System を構
成する要素は次のでとくで，先の $2.74 \mathrm{~m}$ の翼幅増加 あ合めてシステムの全重量は約 $453.6 \mathrm{~kg}$ である.

a. 飛行条件センサー

両翼端の加速度計，重心加速度計およびピッチ・レ ート・ジャイロでいずれす 2 重チャンネルである.ぼ 亿 2 重チャンネルの水平安定板位置センサ (position linear variable displacement transducers) 捄よひ column force sensors（この二つは現在の L-1011 の 自動操縦装置の一部）もまた Active Control System の一部として使用される.

\section{b. システム計算機}

上記センサからの信号をうけて，計算処理した後外 側補助翼および水平安定板サーボへの命令信号を出 す.
c. 外側補助翼系サーボ
c. 水平安定板ピッチ系サーボ
e. 接続機器 (Interface Hardwares)

\subsection{USB (Upper Surface Blowing)}

2.4.1 開発の経緯 この新しい動力利用高揚力装 置は、ボーイング社が AMST (Advanced Medium STOL Transport) と掰する C-130輸送機の後継機 プログラムに参画して，YC-14 を開発する過程にお いて開発したむのである. その最大の原動力は, 強い コスト低下の要求を満たすためにぜひとす双発にした いとの要求に答えたむのであった，開発当時利用可能 の動力利用の高揚力装 置としては，第 13 図に示す EBF (Externally Blown Flap) で, 競争相手の McDonnell Douglas 社の YC-15 はこの方式を採用する 4 発である. EBF を使用しながら着陸しようとして いるときに， 1 発エンジンが停止した場合の安全のた めに 4 発にすることが常識であった。

双発はコスト的に 4 発に勝ることは明らかである
( $E B F)$

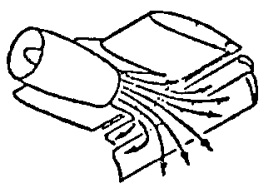

Loteral Spreading Due to Re-Entrant Corner Eliminated

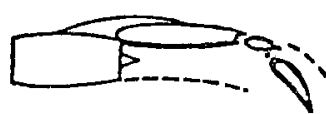

Interference Losses Due to Choking, Etc. in Slots Eliminated $(\cup S B)$
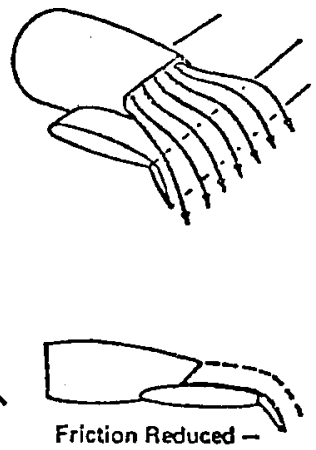

150\% of Flap Surface Wetted by Slipstream Eliminated)
第13図 EBF と USB の比較 


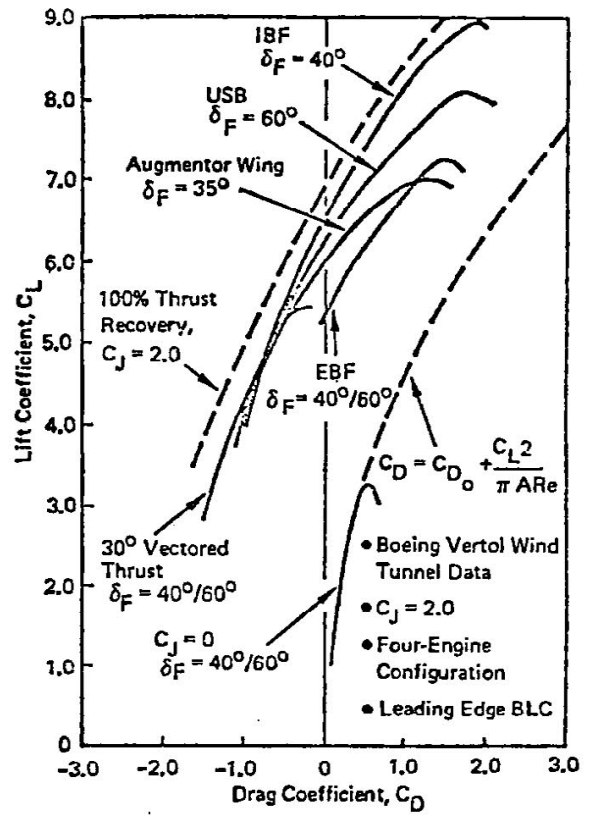

第 14 図 各雬推力利用高場力装置の特性

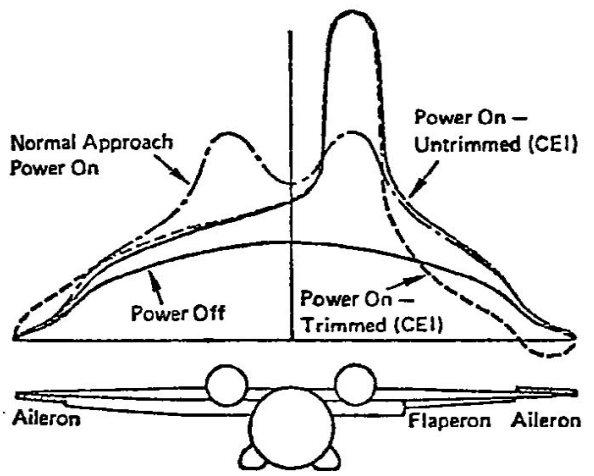

第15図 USB 揚力分布

が，双発にしたときの 1 発停止の危険を解決する唯一 の方法は，エンジンを翼上しかも胴体中心になるへくく 近い位置佶備することであるとの発想から USB が 生まれた。

2.4.2 構造と性能 第 13 困に示すごとく翼上面 にエンジン排気ノズルが開口している．EBF に比し
て，排気のうち側方にロスとして流れる量が少なく， 有効に高揚力化することおよびフラップの簡素化に関 連していわゆる Wetted Surface が少なく，摩擦抵抗 が減少する効果がある，風胴試験による比較試験の結 果は第 14 図のと抢りで，EBF に比してはるかに良好 な揚力を示している，余談であるが図中には，USB よりさらに良好な IBF (Internally Blown Flap) の データが出ているが，実機に適用するにはなお多くの 技術的問題が残っていると聞いている.

2.4.31発停止時の処置 第 15 図に着陸前の USB 便用中の主翼上の揚力分布を銷線で示している，エン ジンの出力は $70 \%$ である. 万一右舷のエンジンが停 止した場合には，ただちに残ったエンジンを全開にす ると図中実線のでとき揚力分布となり，とりあえず揚 力の不足をカバーする. 同時に, 補助翼およびフラッ ペロンを作動すると, 最終的には破線で示す揚力分布 となり飛行機は横の釣合を維持しながら着陸するとと ができるわけである.

2.4.4 その他の効用 第 16 図は着陸時に使用する 逆推進装置とその使用状況を示するのである．てれに ついて三つの効用を指摘することができる.

第 1 は騒音の減少である．エンジンの騷音のうちお あに後方ノズルから出るタービンと排気の騒音は大き な部分を占めているが，エンジン翼上装備の関係上， ズルから出た音が翼上面にて反射，上方に搪散するた め下方への騒音が減少するむのと期待される。

第 2 は戦術場面で，応急に鍛圧した滑走路でのST OL (凋走路長 $600 \mathrm{~m}$ ) 使用が考えられているが，従来 のごとき逆推進装置で下方に排気が曲げられたときに は，むうむうたる砂塵を捲き上げることも考えられ る，第 16 図左の図にみるごとくUSB の場合には， すべての排気は上方に捲き上がるのでそのような心配 はなさそうである。

第 3 はての装置によって上方に排出される排気の反 力によって，主翼は下方に強く押し下げられる．通常 飛行機は着陸時滑走路面に接地しても，速度がおちな い間は翼の揚力のためにブレーキが有効に使用できな い，USB の場合には前記下方力によってずっと早く
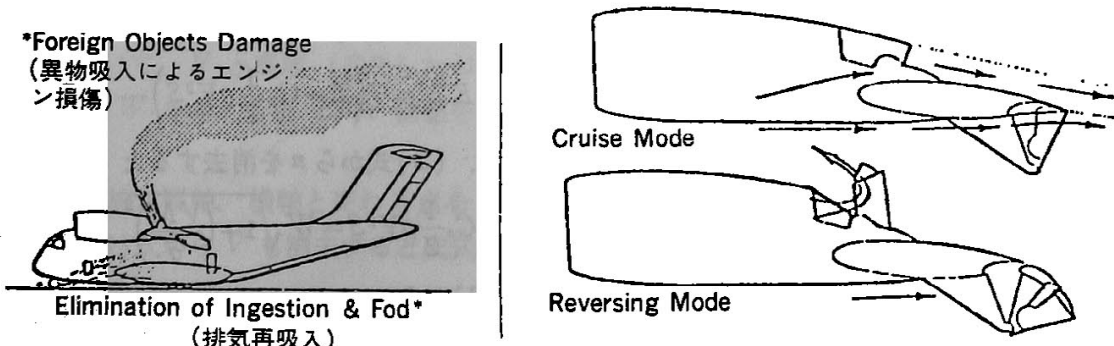

第 16 図USB の逆推進装睘 
からブレーキを有効に使用することによって，着陸滑 走距離を大いに短縮できることが期待される.

\section{3. 戦闘機の新技術（実現済みのもの）}

3.1 戦闘機の空戦性能と E-M 曲線 戦闘機の空 戦性能に影響を与える要因には，てれからとりあげよ うとする E-M 曲線のほ加にす，最大速度・飛行特性 (失速・バフェッティング等)・視界また最近では耐 $\mathrm{G}$ 能力を高めるための傾斜座席などさまざまなものがあ るが，空戦域など運用的な分野を含めて詳細は参考文 献文を参照されたい.

なお AAM（空対空誘導ミサイル）の進歩によって 戦闘機の空戦性能の必要性について疑問をむつ向きむ あるが，現在の AAM は対爆整機用の耐 G 能力の低 いすのが主体であって，格䦙戦 AAM の出現はこれ からである，たとえ格闘戦 AAM が出現してす，こ れですべての勝敗がつく保証はなく，また戦闘機が固 定譏鋕を装備する以上最終的には格闘戦は存在すると みるのが正しい予見と考える，

最近の戦闘㙨に関する新技術の開発の主力が，操綻 性，運動性，上异力等の格闘戦の改善進歩に関するむ のである事実からみてす上記予見の妥当性は証明され ているとみてよかるう.

さて標記の E-M とはエネルギーと運勳性 (Maneuverability) に関する概念で, JOHN BOYD 中佐と THOMAS P. ChRISTIE 氏によって開発されたむので ある。ある戦闘機の戦闘性能を表現するためにすまた 2 機種以上の戦闘㙨の比較をするためにもきわめて有 用なものである。

与えられた速度と高度に拈けるエネルギーの測定変

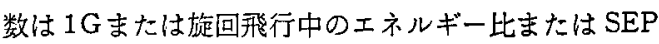
(Specific Excess Power) であって，瞬間的な加速， 減速または水平飛行および旋回飛行中の上昇率で表わ される。

旋回性能の変数としては，荷重倍数(G)，旋回率ま たは旋回半径が考えられるが，これらのうち旋回率が 戦術的に重要であると考えられている，その理由は旋 回半㹩ないしは荷重倍数が一定でも，速度によって方 向変化の割合が変わってくるからである、旋回率こそ 方向変化の割合を表わすすので，速度変化の影響をう けない最適のものである。

第 17 図は E-M 曲線の一例で, 飛行機の $T / W$ 上 (推力対重量比) および $W / S$ (翼面荷重) の影響が変 数として描かれている.

$3.2 \mathrm{E}-\mathrm{M}$ 亡飛行機の各種特性值との関係 第 18

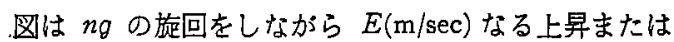
下降を行なっている状態を示すすのとする，以下使用
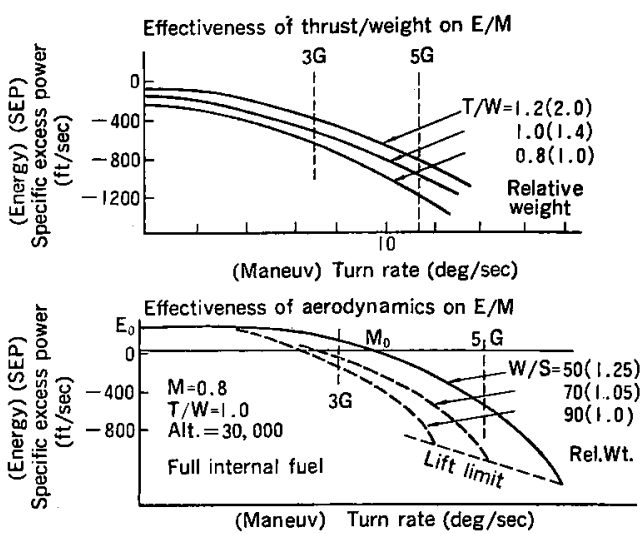

第 17 図 Energy-Maneuverability 曲線

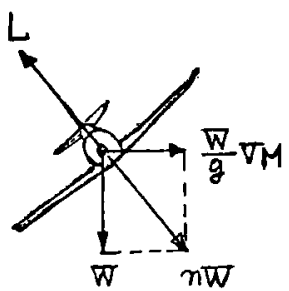

第 18 図旅回上昇（下降）中の飛行機に樹く外力

する記号は次のとおりである.

$E$ (energy) $=\operatorname{SEP}(\mathrm{m} / \mathrm{sec})$

$M$ (maneuverability) =turn rate $(\mathrm{rad} / \mathrm{sec})$

$W=$ 全備重量 $(\mathrm{kg})$

$V=$ 速度 $(\mathrm{m} / \mathrm{sec})$

$g=$ 重力の加速度 $\left(9.8 \mathrm{~m} / \mathrm{sec}^{2}\right)$

$n=$ 荷重倍数

$L=$ 揚力 $=C_{z} \rho V^{2} S / 2(\mathrm{~kg})$

$D=$ 抗力 $=C_{x} \rho V^{2} S / 2(\mathrm{~kg})$

$C_{x}, C_{z}=$ それぞれ抗力，揚力係数 $\left(C_{\mathrm{D}}, C_{\mathrm{L}}\right.$ 上同一)

$\rho=$ 空気密度 $\left(H=0\right.$ で $\left.1 / 8 \mathrm{~kg} \cdot \mathrm{sec}^{2} / \mathrm{m}^{4}\right)$

$S=$ 主翼面積 $\left(\mathrm{m}^{2}\right)$

$T=$ エンジン推力 $(\mathrm{kg})$

釣合の条件式は次の三つとなる。

$$
\begin{aligned}
& L=C_{x} \frac{1}{2} \rho V^{2} S=n W \\
& \eta^{2}=1+\left(\frac{V M}{g}\right)^{2} \\
& E W=V\left(T-C_{x} \frac{1}{2} \rho V^{2} S\right)
\end{aligned}
$$

(1)，(2)式加らnを消去すると

$$
C_{z} \frac{1}{2} \rho V^{2} S=W \sqrt{1+\left(\frac{V M}{g}\right)^{2}}
$$

(3) 加

$$
C_{x} \frac{1}{2} \rho V^{2} S=T-\frac{E W}{V}
$$


第 1 表 新戦閳機要目比較表

\begin{tabular}{|c|c|c|c|c|c|c|c|c|c|c|c|c|c|}
\hline 機 名 & $\begin{array}{l}\text { Flyaway } \\
\text { cost } \\
\text { (Program } \\
\text { Unit } \\
\text { Cost) } \\
\$ \mathrm{M}\end{array}$ & $\begin{array}{l}\text { Max } \\
\text { T.O. } \\
\text { Wt. } \\
\text { (lb) }\end{array}$ & $\begin{array}{l}\text { Normal } \\
\text { T. O. } \\
\text { Wt. }{ }^{* 1} \\
\text { (lb) }\end{array}$ & $\begin{array}{l}\text { Design } \\
\text { Combat } \\
\text { Wt. }{ }^{* 2} \\
\text { (lb) }\end{array}$ & $\begin{array}{l}\text { Engine 名-推 } \\
\text { 力-数 } \\
\text { (lb) }\end{array}$ & $\begin{array}{l}\text { 席 } \\
\text { 数 }\end{array}$ & $\begin{array}{c}\text { 内部燃料 } \\
\text { (含外部 } \\
\text { 燃料) } \\
\text { (lb) }\end{array}$ & $\begin{array}{c}\text { Wing } \\
\text { Area } \\
\left(f t^{2}\right)\end{array}$ & $\frac{\text { Fuel*s }}{\text { GW }^{* 1}}$ & 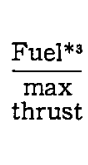 & $\begin{array}{l}W^{*_{2}} / S \\
\left(\mathrm{lb} / \mathrm{ft}^{2}\right)\end{array}$ & $T / W^{* 2}$ & 記 爭 \\
\hline $\mathrm{F}-14 \mathrm{~A}$ & 11.6 & 65,000 & 55,200 & 47,000 & $\begin{array}{c}\text { TF } 30-\mathrm{P}-412 \\
(20,950) \times 2 \\
41,900\end{array}$ & 2 & 16,445 & 565 & .298 & .392 & 83.2 & .891 & 実用中 \\
\hline F-15 A & 12.3 & & 42,000 & 35,400 & $\begin{array}{c}F 100-P W-100 \\
(25,000) \times 2 \\
50,000\end{array}$ & 1 & 13,200 & 608 & .314 & .264 & 58.2 & 1.412 & 実用 中 \\
\hline F-16 A & $\begin{array}{r}4.5 \\
(6.7)\end{array}$ & 33,000 & 22,200 & 18,700 & $\begin{array}{c}F 100 \mathrm{PW}-100 \\
(25,000) \times 1 \\
25,000\end{array}$ & 1 & 7,000 & 280 & .315 & .280 & 66.8 & 1. 337 & 7 開 発 中 \\
\hline$F-18 \mathrm{~A}$ & $\begin{array}{r}5.8[75] \\
(9.6)\end{array}$ & 44,000 & 33,720 . & 28,290 & $\begin{array}{c}\text { F } 404-G E-400 \\
(16,000) \times 2 \\
32,000\end{array}$ & 1 & 10,860 & 400 & .322 & .339 & 70.7 & 1. 131 & 開 発 中 \\
\hline $\begin{array}{l}\text { F-18L } \\
.(\text { Cobra } \\
\text { II) }\end{array}$ & $4 \sim 4.5$ & & 27,400 & 23,150 & 32,000 & 1 & 8,500 & 400 & .310 & .266 & 57.9 & 1. 382 & $\begin{array}{l}\text { 開発自社) } \\
\text { (1) }\end{array}$ \\
\hline $\begin{array}{l}\text { Mirage } \\
\text { F1E }\end{array}$ & & & 33,500 & 29,800 & $\begin{array}{c}\text { SNECMA } \\
\text { M } 53 \times 1 \\
18,500\end{array}$ & 1 & 7,385 & 269 & .220 & .399 & 110.8 & .620 & 開 発 済 \\
\hline MRCA & 8 & 40,000 & 36,000 & 30,500 & $\begin{array}{c}\text { RB } 199-34 \mathrm{R} \\
(15,500) \times 2 \\
31,000\end{array}$ & 2 & 11,000 & 397 & .306 & .355 & 85.9 & 1.016 & $\begin{array}{c}\text { Flt Test } \\
\text { 中 }\end{array}$ \\
\hline $\begin{array}{r}\text { Mirage } \\
\text { (Delta) } \\
4,000\end{array}$ & $12[75]$ & & 44,000 & & $\begin{array}{r}\text { SNECMA M } 53 \\
(18,500) \times 2 \\
37,000\end{array}$ & & & & & & & & $\begin{array}{l}\text { 閒発中 } \\
\text { (翰出用) }\end{array}$ \\
\hline F-104 J & & 24,207 & 21,225 & 18,500 & $\begin{array}{c}\mathrm{J} 79-\mathrm{GE}-11 \\
15,800\end{array} \times 1$ & 1 & 5,825 & 190 & .274 & .369 & 97.4 & .854 & = 実用 中 \\
\hline$F-4 \mathrm{E}$ & & & 47,000 & 40,207 & $\begin{array}{c}\mathrm{J} 79-\mathrm{GE}-17 \\
(17,900) \times 2 \\
35,800\end{array}$ & 2 & 13,587 & 530 & .289 & .380 & 75.9 & .890 & 実 用 中 \\
\hline $\begin{array}{r}\text { Mirage } \\
\text { F } 1\end{array}$ & & & 33,000 & 29,300 & $\begin{array}{l}\text { SNECMA } \\
\text { Ator } 7 \mathrm{~K}-50 \times 1 \\
\quad 15,800\end{array}$ & 1 & 7,385 & 269 & .224 & .467 & 108.9 & .539 & 実用中 \\
\hline $\begin{array}{l}\text { Viggen } \\
37 \mathrm{E}\end{array}$ & & & 35,273 & 30,313 & $\begin{array}{l}\text { Volvo RM } 8 \text { B } \\
28,108\end{array}$ & 1 & 9,920 & 495 & .281 & .353 & 61.2 & .927 & 7 実用中 \\
\hline
\end{tabular}

(4)，(5)から

$$
\frac{L}{D}=\frac{W \sqrt{1+\left(\frac{V M}{g}\right)^{2}}}{T-\frac{E W}{V}}=\frac{\sqrt{1+\left(\frac{V M}{g}\right)^{2}}}{\frac{T}{W}-\frac{E}{V}}
$$

(6)から $E, M$ を求めると次のようになる.

$$
\begin{aligned}
& E=V\left[\frac{T}{W^{2}}-\frac{\sqrt{1+\left(\frac{V M}{g}\right)^{2}}}{L / D}\right] \\
& M=\frac{g}{V} \sqrt{\left[\frac{L}{D}\left(\frac{T}{W}-\frac{E}{V}\right)\right]^{2}-1}
\end{aligned}
$$

(7)，（8）式を用いて，Vと高度（迎角したがって $L / D)$ を定めて $T / W$ を与えると $E-M$ 曲線を引く ことができる.

さらに $E-M$ 曲線が縦軸，横朝と交わる点を $E_{0}$, $M_{0}$ として (7)，(8)式からV あ消去すると次式が得 られる.

$$
E_{0}=\sqrt{\frac{W}{S} \cdot \frac{2}{\rho C_{2}}}\left[\frac{T}{W}-\frac{1}{L / D}\right]
$$

$$
M_{0}=g \sqrt{\frac{\frac{L}{D} \frac{T}{W}-1 / \frac{L}{D} \cdot \frac{T}{W}}{\frac{W}{S} \cdot \frac{2}{C_{z} \cdot \rho}}}
$$

$E_{0}$ および $M_{0}$ が大きいほど，空戦性能が良好とい うわけであるが，それぞれに影響を及ぼす要因はたん に $T / W$ と $W / S$ のみでなく，ほかに $L / D, C_{x}$ か 大きな要因であることが判明する，こてで注目すべき ことは，T/W 比およひ $L / D$ は文句なしに大きいほ ぞ $E_{0}, M_{0}$ に好影響を与えるが，W/S・C $C_{z}$ は小さい ほど $M_{0}$ には好影響を与えるが $E_{0}$ に対しては逆効 果のあることである，第 17 図の下の図においてW/S をパラメータとした曲線群が $M$ の小さいところで交 わっていることは，このことを証明している.

3.3 最近の戦闘機の $T / W$ および W/S 第 1 表 と第 19 図は最近戦閾機の要目とくに $T / W$ および W/S を示すものである.

F-15 A，F-16 A，F-18 A および MRCA よ゙の最 新戦閶機が設計戦闘重量時の $T / W$ 比が 1 を超す高 


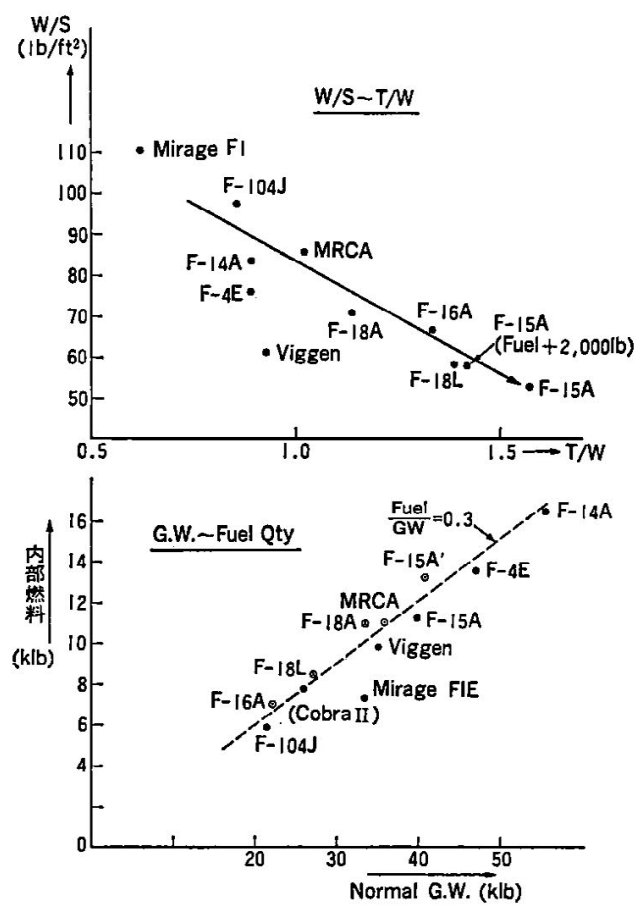

第 19 図 最新戦䦥機の $T / W, W / S$ 等
出カエンジンを装備している状況が看取される，また 翼面荷重も推力の余裕を活用して小さくなりつつある ととが判明する.

汃くごとき高い $T / W$ 比実現の主役は，後述の めざましいエンシンンの進歩，複合材料およびチタン使 用に上る機体構造重量の軽減，電子技術の進歩に上る 小型軽量化などを挙げるととができるが，本節におい てはおすに $L / D, C_{z}$ の改善に貢献している新技術に ついて紹介することにする.

3.4 可変後退翼と可変カンバー翼 超音速機们お いては，超音速実現のために翼は薄くかつカンバーの 小さい翼とならざるをえない，とうせんの結果として $L / D$ は覀くなり， Cz は小さくなる，離着陸性能，航 続性能㧍よび空戦性能の悪化をきたす結果となる，そ てで低速における対策として翼厚を回復しようとする 試みが可変後退角 (Variable Geometry) であり，てれ が不可能な固定翼機幟採用されている方式がカンバー を回復しょうとする可変カンバー (Variable Camber) である.

可変後退翼は，F-111 ではじめて実現され，その 㣪 F-14 A，B-1 および欧州の MRCA（多目的戦閾機 ・英独伊共同開発）などに採用されている，第20四 は MRCA のものである.

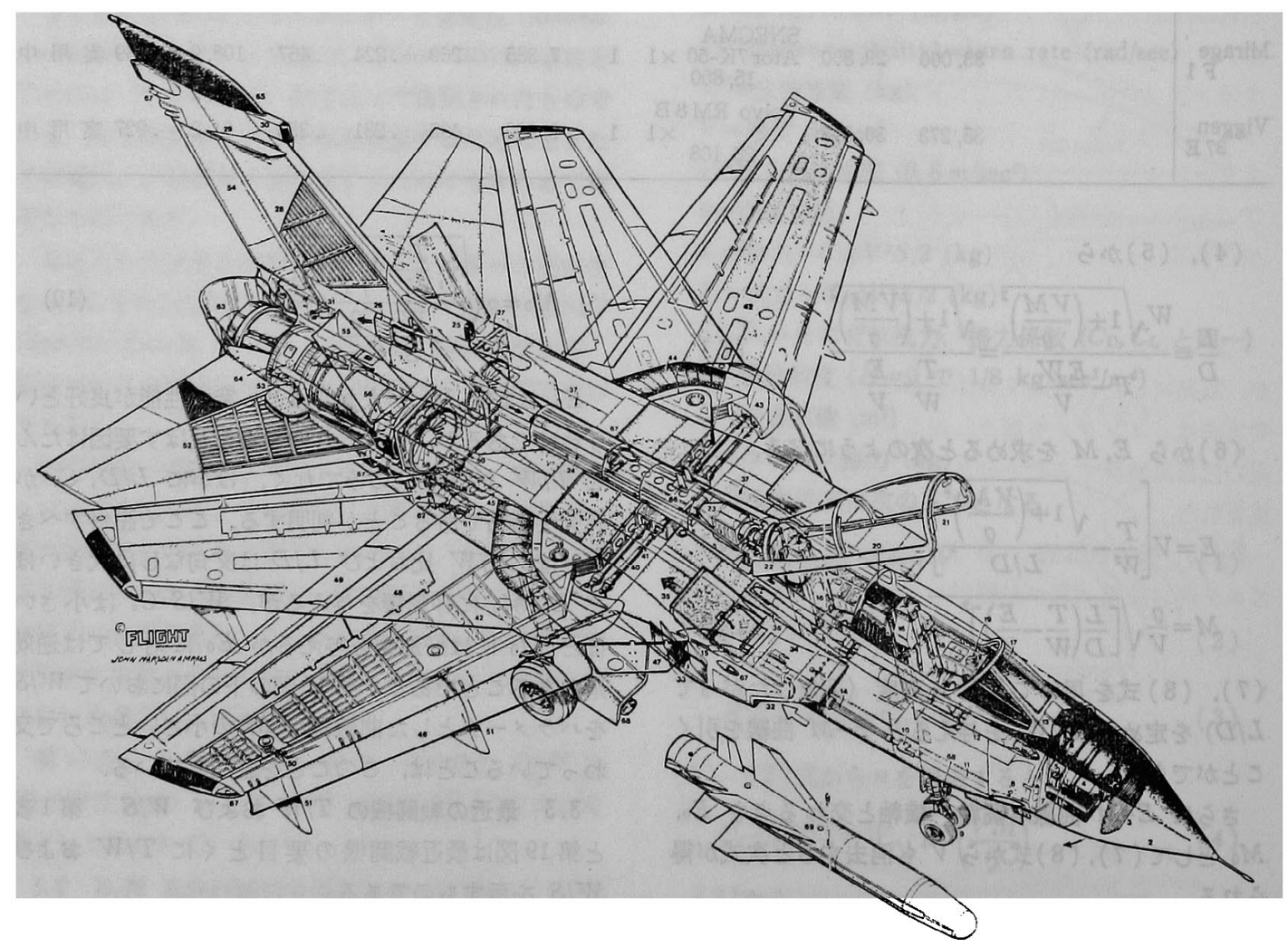

第20図 MRCA の可変後退琶 

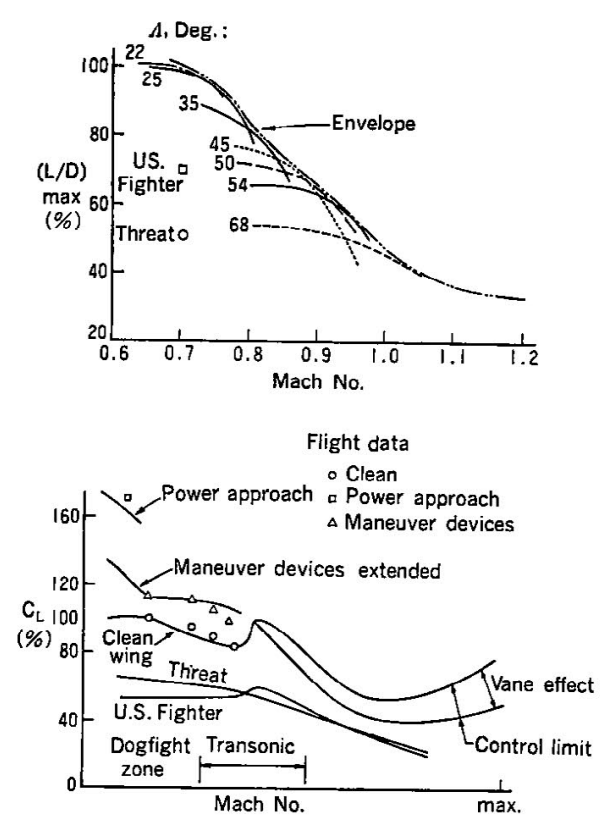

第 21 図 F-14A 可変翼珷の $L / D$ およひ $C_{\mathrm{L}}$

第 21 図は F-14A の全速度域婂おける $L / D$ およ び $C_{2}\left(C_{\mathrm{L}}\right)$ を示すすのである. $0.7 \mathrm{M}$ あたりの低速 では，可変翼の F-14 に比して固定翼機は， $L / D$ で 約 $70 \%, C_{z}\left(C_{\mathrm{L}}\right)$ で $50 \%$ 以下しかないととが明瞭俚 解される.したがって第 19 図の $T / W$ 比之W/S の 比較だけで簡単に空戦性能をうんぬんすることの誤り を十分認識しなければならない。

可変カンバーについては第 22 図の Maneuver Flap の効果 $\left(C_{x} 1.4 \rightarrow 1.6\right)$ でその增加比率を知ることがで きる.

3.5 前縁延長 (Leading Edge Extension) 第 22
四に示すでとき翼根部の前縁を胴体側面にそって前方 に延長したすので本図は F-18A のむのである，F-16 A では同じ形式のものを Controlled Vortex Lift ま たは Forebody Strakes とよんでいる，前縁延長部か ら発生した渦のエネルギーが翼付根部に㗢いてとくに 迎角の大きいとてろで，失速をおくらせ大きな揚力を 与えるととは，右図によって明らかである，前縁延長 のない場合の $C_{x}$ が 0.85 程度であるのに比し， 1.4 まで増大し $60 \%$ 以上の向上効果を発揮している.

空戦能力の向上に資するほか着陸時の着速減少に貢 献することはとうぜん予想されるが，さらに大きな迎 角に扔いて方向安定をよくする効果のあるととす認め られている. なお F-16A の場合にはての延長によっ てピッチングモーメント曲線が直線となるので，トリ 么抵抗が减少するという効果む認められている，

3.6 翼胴一体化 (Wing Body Blending) F-16 A で埰用された新技術の一つである，第 23 図にみられ るように構造的に翼胴が一体化して円滑な断面変化と なっているため，本節でとりあげた胴体揚力增加によ る空戦性能への寄与以外に次の上うな各種の利点を生 じている.

a、断面皘曲線の滑かな変化によって面積分布が改 善され，遷音速における抵抗が減少する。

b. 外部 Wetted Area/体皘比加改良される.と くに翼は根部が厚くなるので, 構造的に楽になりそれ による重量節約は $113.4 \mathrm{~kg}$ である.

c. 体積/燃料分布比がよくなり, 内部燃料の容皘 が増大するのみならず, 重心の移動が少なくなる。

d. 胴体全長が短くなる．胴体内部然料の関係およ び Relaxed Static Stability の関係で, $1.67 \mathrm{~m}$ む胴

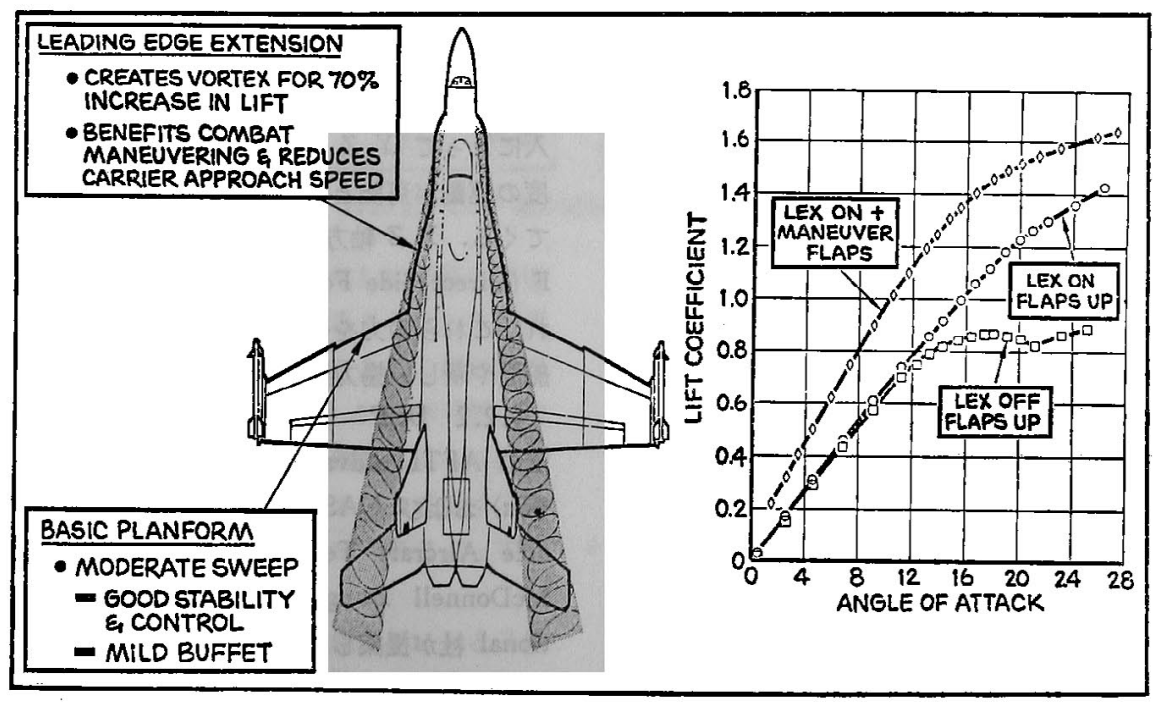

第22区 F-18 の前縁延長 (LEX=Leading Edge Extension) と Maneuver Flap の効果 


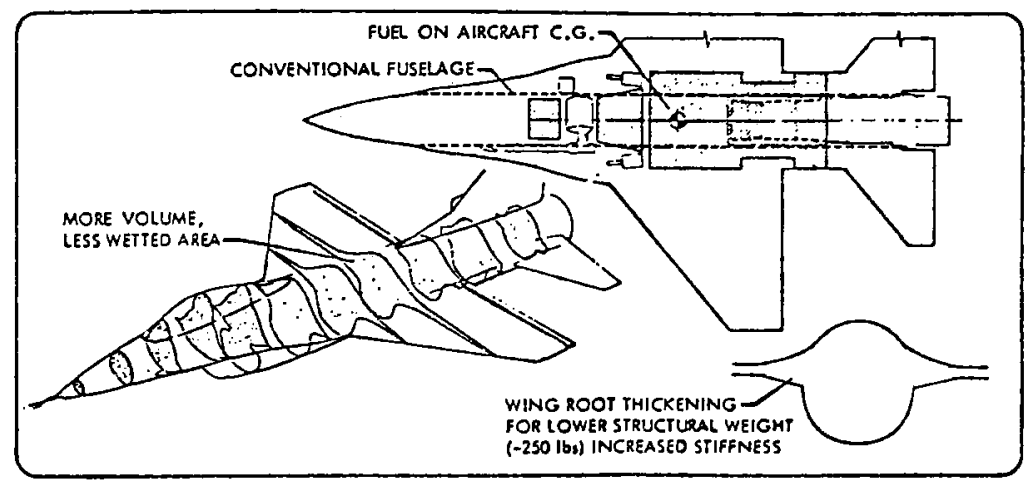

第 23 図 F-16 A の缹胴一体化

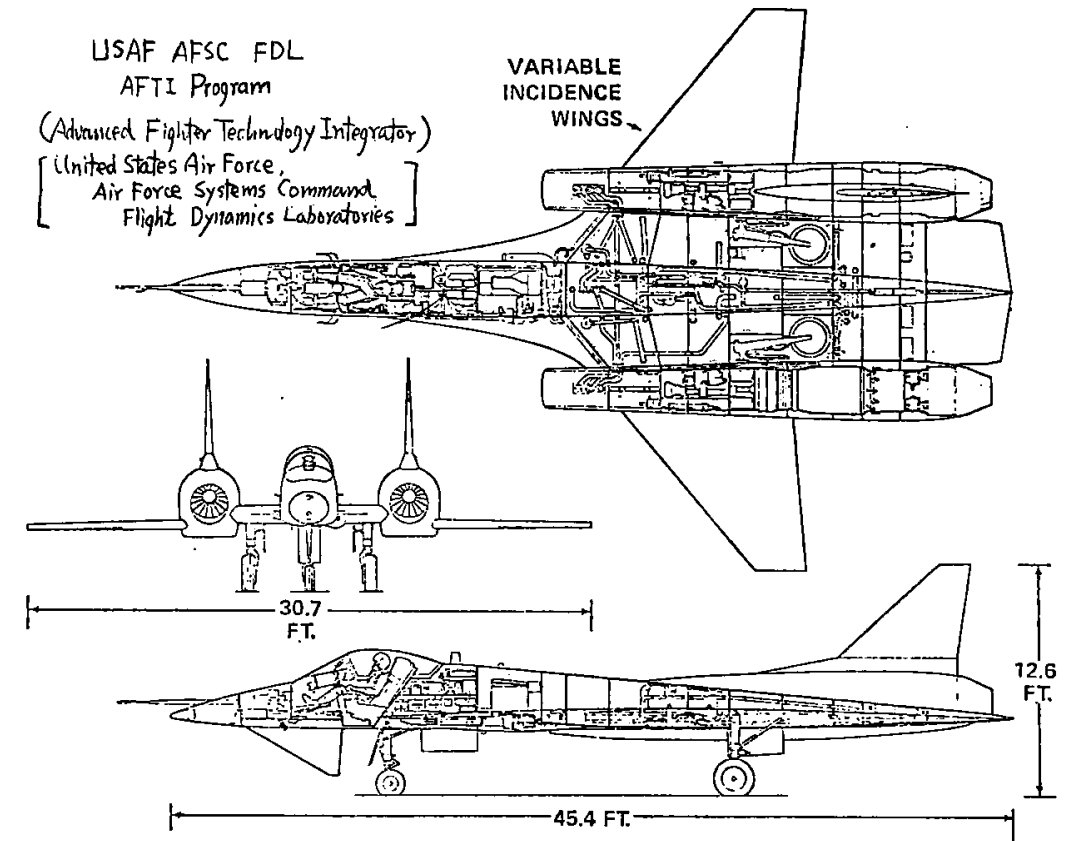

第 24 図 米空軍/マクドネル・ダグラス社 AFT 1 プログラム計画機

体を短縮でき，145 kg の重量軽減をはかることがで きたといわれる.

\section{C. C. V. (Control Configured Vehicle)}

4.1 定義 コンピュータを利用するととによって 可能となった新しい Control 方式 (DL と DSF) や Relaxed Static Stability などを考慮に入れて，形態 (Configuration) を定めた飛行㙨のことをいう. FBW (Fly by Wire) は，とれを実現するための必須の手段 である。

\section{2 操糹性 (Maneuverability)}

4.2.1 DL と DSF（直接揚力と直接横力）従来 の航空譏の操縦は，エンジンの推力調整と抵抗の増減 （抵抗板・抵抗采な゙）によるX 方向の加减速と， 3 舵による $X, Y, Z$ 軸まわりの回転運動の四つの自由
度によって必要な運動を行なってきたが，CCV の導 入によって $Y, Z$ 軸方向の運動加追加されて，6 自由 度の運動が可能となり，新しい飛行制御方式が生まれ てくる. $Y, Z$ 軸方向の運動を与える力はそれぞれ DS F (Direct Side Force) と DL (Direct Lift) とよば れ、乙れらの力を発生するために後述のでとき新しい 舵面や新しい揚力発生機構が必要となる.

4.2.2DSF 第 24 図と第 25 図はそれぞれ，米空 軍の AFTI (Advanced Fighter Technology Integration) および NASA の HiMAT (Highly Maneuverable Aircraft Technology) プログラムに対して, McDonnell Douglas 社および Rockwell International 社が提案した計画機である，第 24 図では機首 下面の可動垂直フィンと 2 枚の尾部垂直フィン (可動) の作用によって DSF を発生する，DSF を利用して 

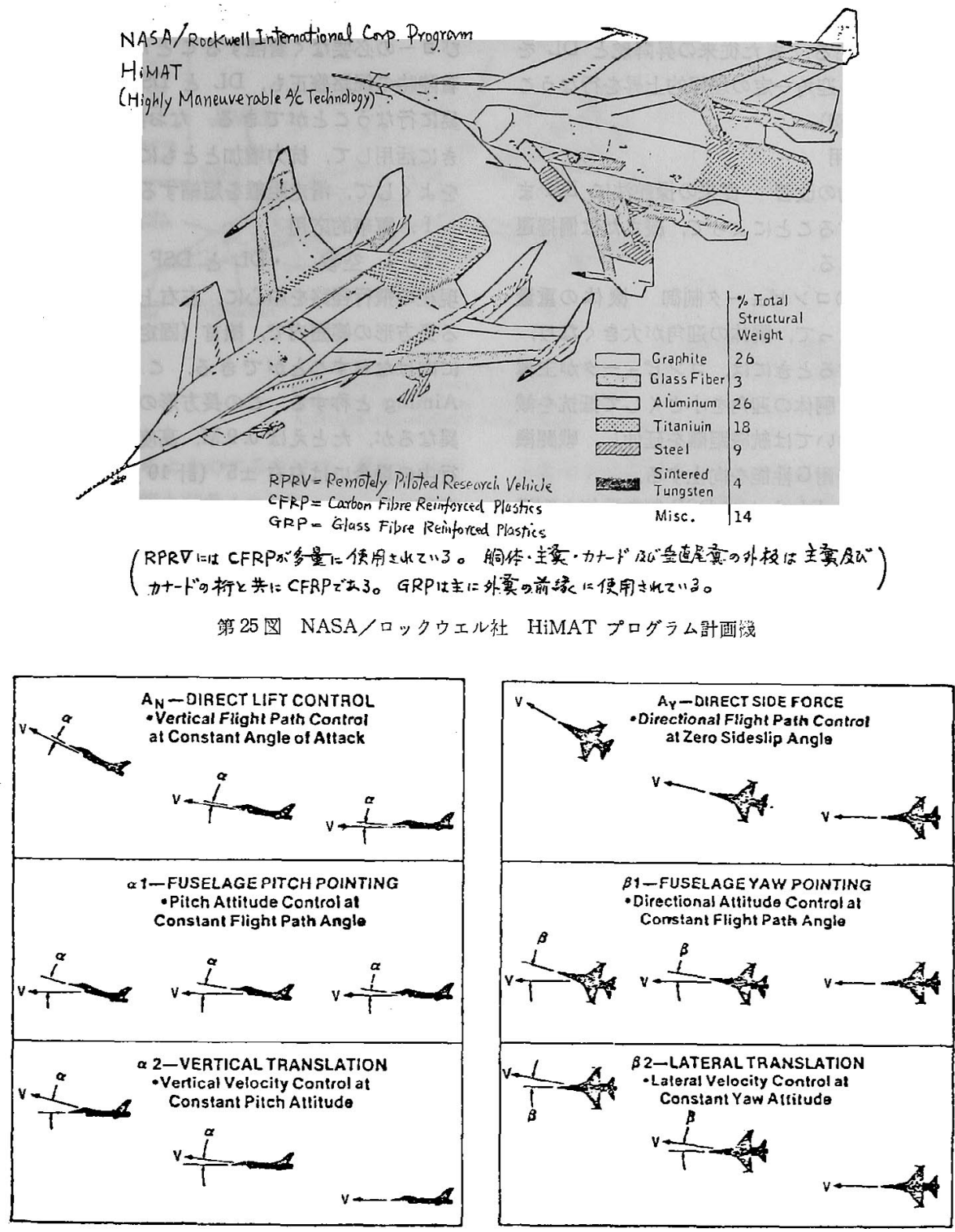

第 26 図 CCV 機の縦および方向制御モード

機軸方向を変えず，バンクするととなしに航路を右ま たは左に移動させること，バンクすることなしに旋回 運動を行なうことおよびバンクするととなく飛行径路 に対して機首をふった飛行を行なうととが可能とな る.とうぜんのてとながらてれらの操縱によって生ず るローリングおよびョーイングモーメントに対する調 整は, 後述の各種センサーとコンピュータによって制 御される(第 26 図参照).

第 25 図では主翼端の 2 枚の可動垂直フィンと 2 枚 の尾翼可動フィンにより DSF を発生している.

4.2.3 DL HSA (Howker Siddeley Aviation)
開発のハリア一戦䦥機のエンジン排気の垂直下方への 変向に上る揚力発生む一種の DL であるが, 空戦その 他の目的に自由に活用するためには縦の釣合をコンピ ュータによって維持するてとが必要で，ハリアーは真 の CCV よはいえない.

第 24 図では外翼の迎角変更 (Variable Incidence)

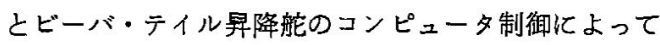
DL を発生している，第 25 図では前翼の迎角変更と 昇降舵のコンピュータ制御によっている．いずれの場 合にあ，飛行機の機首を上下に動かすことなく，上方 または下方に飛行烽路を平行移動させることはむちろ 
ん，等高度飛行を続けながら機首を上また下に傾斜さ せることむ可能である．また従来の昇降舵と DL を 併用して径路に対し迎角一定の理想的上昇を行なうこ ともできる(第 26 図).

\subsection{4 効果之応用}

a. 縦・偏摇運動の改善 従来の操舵法に DL ま たは DSF を追加することによって，縦または偏摇運 動が敏速に行なわれる。

b. 最適 $L / D$ のコンピュータ制御 機体の重量 変化や高度変化仿よって, 胴体の迎角が大きくなり,

胴体の抵抗が増加するときには、コンピニータが主翼 の迎角を修正して，胴体の迎角を小さくして抵抗を減 小する，民間機においては航続距離を延伸し，戦闘機 では一定速度下での耐 $\mathrm{G}$ 性能を向上する.

c 、突風の緩和 DL および DSF 制御機能を利用 して，そ㣗ぞれ垂直突風および水平突風忆よって発生 する加速度を消失させるととができる，乗員・乗客の 快適性を向上し，機体の表命を延伸するほか，軍用機 においては，武器発射プラットフォームとしての安定 性を増加させる。

d. 抗力の調節 DL の機構たとえば可変迎角を 利用して，左右船同時に一定角度変更させることによ り，抗力の調節ができるので，抵抗板などのブレーキ は不必要となる。

\section{e. 離着陸}

e. 1 離陸 DL を利用すれば機首を上げること なく機体を浮揚させることができる，パイロットの視 界は良好でありまた機首上げによる急激な抵抗増加に 起因する失速や機外装備品と地面との間隔に対する緊 念は不要となる。

e. 2 着陸 着陸時の大きな障害となる横風に対
しては，DSF を利用するてとによって，バンクおよ びョーの必要なく着陸するととができる．また ILS 着陸時の経路修正む，DL と DSF の利用によって容 易に行なうことができる．なお接地後は DL を下向 きに活用して, 抗力増加ととむに車輪ブレ一キの効き をよくして，滑走距離を短縮することができる．

f. 軍事的応用

f. 1 空戦 D DL と DSF を利用すると空戦時 現在の飛行径路を中心沉，左右上下特定の角度ででき る長方形の範囲内で，機首（固定機銃の方向）を自由 に向けな标すことができる．この能力を Fuselage Aiming と称する。 との長方形の大きさは飛行状態で 異なるが，たとえば $0.9 \mathrm{M}$ ，高度 $3,048 \mathrm{~m} ， 1 \mathrm{G}$ で飛 行中の場合化は左右 $\pm 5^{\circ}$ (計 $10^{\circ}$ ), 上方 $11^{\circ}$ 下方 $10^{\circ}$ $\left(21^{\circ}\right)$ となる，乙の長方形は必要な見越角に利用でき るので，従来の照準装置ではずれてしまうような大見 越角も可能となる見地加ら将来の利用価值が期待され る.ただし Fuselage Aiming む長方形の周辺化近つ く之急激に抵抗肪增加するので, 使用上の制限とな る.

- 正面攻摮のときは飛行径路から急に脇にそれて敵 機をやり過ですことができるので，正対飛行できる時 間む長くなり，また正面衝突の危険む回避できる.

・敵機が有利な位㯰についた場合には，前述の抗力 調節になる急减速（-2G で有効）によって敵機をや り過ですことができる.

・また最大推力飛行中に大きな抗力増加を行ない, 次いで抗力を急汇解放して急加速を行なうことす可能 である.

f. 2 対地攵罂 ・パイロットは機体をバンクさ せないで, 水平のまま経路変更ができるので, 目標の

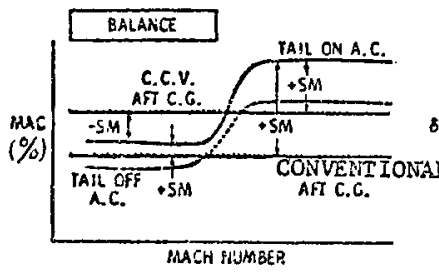

( $S M=$ Siatic Margin)
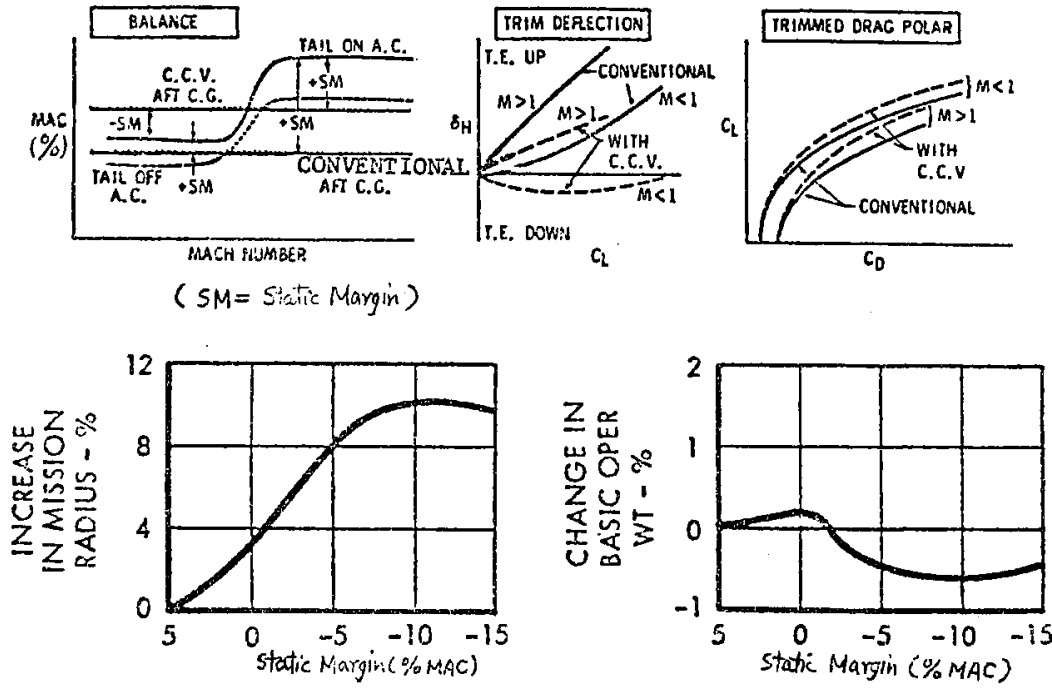

第27 図 F-16 A RSS (Relaxed Static Stability) の効果 


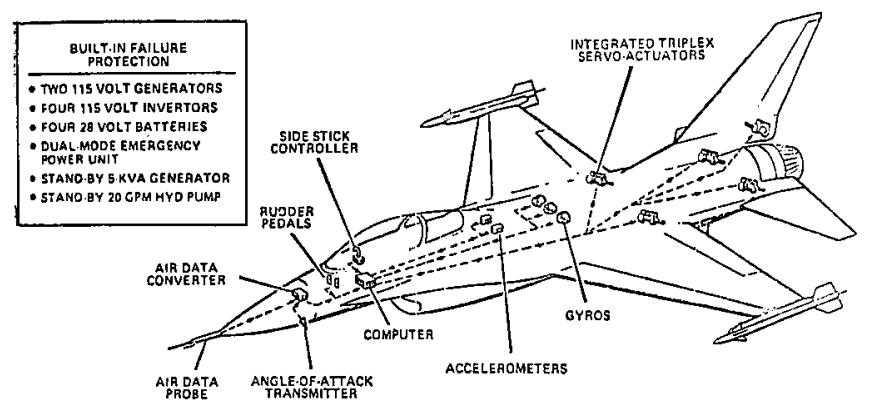

A QUAD-REDUNDANT SYSTEM PROVIDING SAFE FLIGHT WITH THREE FAILURES, STALL AND STRUCTURAL PROTECTION, AND

第 28 圆 F-16A の CCV 関連装俏 品之 FBW (Fly by Wire)
真上に飛行径路をとるようにするだけで，爆弾などの 高精度水平爆撃が可能となる.

・地上掃射に際しては，Fuselage Aiming を㐫用 すると，機首下げのままで一定高度を飛行しながら一 列にならんだ目標を端から端まで射撃することができ る. 急降下射撃の場合には，引起しのため時間の制約 があって攻盤目標数が制限されるので，新しいシステ 么の便益は大きい。

\section{3 安定性 (Stability)}

4.3.1 超音速機の縦安定超音速においては，亚 音速域注ける縦安定を適当にもたせると，超音速域 においては䋛安定が強くなりすきて，運動性を悪くす るのみならず, 縦の釣合いを保つための尾翼荷重が増 大し，構造重量や抵抗の増加を伴うという不具合があ る(第 27 図参照).

そこで重音速域では綐安定負の飛行機を作り CCV 概念を導入してコンピュータ制御により昇降舵を操作 して䚣安定を保持する方式を探用すれば，前述の諸問 題を一挙代解決することができる，これがいわゆる “Relaxed Static Stability” である.

4.3.2 Relaxed Static Stability (RSS と略記) 第 27 四にマッ八数に対する風圧中心の移動之，従来 機の重心の決め方が示されている，超音速域にはいる そ +SM (Static Margin)がはなはだしく大きくなり， Trim Deflection および Trim 抵抗の增加するとと がわかる，F-16A 戦闝機においては，その対策とし て重心位置を思い切って後退させることによりこの問 題を解決している。，下段の四によると SM が $-10 \%$ のとき，行動半径が最大となり $(+10 \%)$ ，また構造 重量も最小となる $(-0.6 \%)$ こが実験データとして 示されている.

McDonnell 社が USAF に提案している AFIT (前 出）プログラムの設計提案においても，SM が $-6 \%$ のとき離陸全備重量が最小となり優れた旋回率が得ら れることが栻験と解析によって判明している。るちろ
ん重心が亚音速では風圧中心より後方にあるため,コ ンピュータによって舵面の調整はほほ継続的に行なう 必要があるといっている.

$4.4 \mathrm{CCV}$ 概念の応用 本章においては， CCV の Control を飛行機の姿勢制御に限定して, 前述の DL, DSF および RSS とそれらの応用による効果を詳述し たが，人によってはさらに広籍囲の Control を考虑 に入れる考え方ああるので，ここに項目のみを揭げる こととし詳細は省略する，とうぜん 2.3 に述べた Active Control System むその一例である.

- MLC=Maneuver Load Control

- FMC = Flutter Mode Control

- $\mathrm{CA}=$ Control Augmentation

- SMC = Structural Mode Control

$4.5 \mathrm{CCV}$ 関連搭載品 第 28 図に F-16 A 戦闘機 の CCV 関連装備品を示す.本機は RSS のみ実用に供 しており，実験的には昨 '77 年米空軍の FDL (Flight Dynamics Lab.) にて改造機により DL, DSF おょび RSS を含む CCV 機の試験を行なっている. CCV 機 においては，本図に DL, DSF 用サーボ・アクチュエ 一タが追加されると考えてよいと思われる.

まずセンサとしては，高度・速度・温度・迎角など の空力データが Air Data Converter を通じ，さらに 3 個のレート・ジャイロ之2 個の加速度のデータが直 接コンピュータに送られる. 操旡の命令は右舷コンソ ールにある小さい操縦棒と足踏ペダルによってコンピ ユータに送られる.コンピュータの操舵指令は電線に よって各舵を動かす 5 個の 3 重サーボ・アクチュエー タに送られるシステムになっている. (以下次号)

\section{参考文献}

1) Aviation Week \& Space Technology (1977/9/19).

2) Fellers, W.E. and Patierno, J. : The Air Superiority Problems, Flight (1970/11/26). 